\author{
Alexander GUGNIN ${ }^{1}$ \\ Grzegorz OSTASZ ${ }^{2}$ \\ Yuliya LISNEVSKAYA ${ }^{3}$
}

\title{
CASTRO II. RAÚL - IDEOLOGICAL LEADERSHIP IN THE ANTILLES
}

\begin{abstract}
The article describes and analyzes the main stages of Raúl Modesto Castro Ruz's political activity- the second most important leader of socialist Cuba. The structure of the article is based on the principles of chronological narration. The conceptual basis of Raúl Castro's ideological outlook has been systematized and generalized. The article pays special attention to his Marxist-Leninist leanings and his closeness with the national liberation ideas of Jose Marti. The article adopts a psychological perspective in describing Raúl's fierce revolutionary struggle in the second half of the 1950s and uses methods from political management showing that Fidel Castro, Raul's brother, allowed Raúl to make his personal management decisions and to implement them often with risks to his life and reputation. For the last 50 years, Cuba's power mechanism can be characterized as a non-classical diarchy of the Castro brothers: Fidel was a common leader, Raúl was a military leader, and from 2006 until the death of Fidel he was controlled by the leadership of his brother. Raúl, during the years of his presidency and after escaping from Fidel's psychological pressure, carried out reforms in the country that were aimed at bringing Cuba closer to a market society. These changes were made in the country yet were limited by Raúl's ideology. Raúl Castro's reforms were related to his denial of the right of the individual to express his own views if they differed from those of the dominant doctrine. However, the reforms didn't influence the development of democracy and freedom of civil rights. Finally, the article describes Raúl's intransigent attitude towards American imperialism and his willingness to defend Cuba's independence and revolutionary achievements.
\end{abstract}

Keywords: political leadership, political marketing, policy-making, geopolitics.

\section{INTRODUCTION}

Castro brothers opened a new era for their country. Together with Fidel, Raúl stood at the origins of the revolutionary movement on the island, laid the foundations of the modern

${ }^{1}$ Professor Alexander Gugnin, DSc, PhD, Department of Marketing, Faculty of Management, Rzeszow University of Technology; e-mail: guga@prz.edu.pl (corresponding author). ORCID: 0000-0002-1997-2876.

${ }^{2}$ Professor Grzegorz Ostasz, DSc, PhD, Department of Humanities and Social Sciences, Faculty of Management, Rzeszow University of Technology; e-mail: gost@ prz.edu.pl. ORCID ID: 0000-0002-7785-9302.

3 Yuliya Lisnevskaya, PhD, Associate Professor, Department of Public Administration and Law, Dnipro Academy of Continuing Education; e-mail: kzvo@dano.dp.ua. ORCID: 0000-0003-3068-0791 . 
Cuban statehood and did much to save the independence and sovereignty of Cuba under the severe external pressure (Farber, 2006; Huberman, Sweezy, 1961; Lievesley, 2004).

This article will be focused on the politician, who for decades was the right hand of its elder brother, the legendary Commander Fidel Castro. About a man who for 10 years from 2008 to 2018, led the implementation of an extremely difficult task: to adapt the outdated Cuban economy to the challenges of the new time. In 2018 he was brave enough to transfer the full power to Miguel Diaz-Kanel, the representative of the generation which did not know the beginning of the Cuban revolution (Eckstein, 2003; Kapcia, 2014).

Raúl is one of the last, if not the least, representatives of the "old Cuban Guard" of the revolutionaries. On January 1, 1959 this Guard overthrew the dictatorial regime of Fulgencio Batista, the American puppet, oligarch and corrupt.

\section{YOUTH AND THE FORMATION OF A WORLDVIEW}

Raúl Castro is the son of Angel Castro, a Spanish native, and his second wife (former servant of Lina Rus Gonzalez). According to some new sources, he is not the sibling, but only half-brother of Fidel (Nevskoe vremya, 2019). This explains the lack of the external resemblance of brothers. The future revolutionary studied at a Jesuit school in Santiago de Cuba. Back in 1937 at the family meeting it was decided that Raúl would continue his education in the so-called "Civil-military school", not far from his native Biran. In January 1938 this school was visited by Batista himself and during the meeting the colonel lured Raúl and put him on his knees. The boy at first looked at the medals on Batista's chest, and then said a phrase, which he had learned by the task of the head of the school: Colonel Fulgencio Batista, on behalf of the pupils of the school, I ask you to promote our sergeantdirector to the military rank of the lieutenant. The future dictator became stupefied and, after keeping some silence, answered: "Well, I will do this". Could he think at that time that this boy would be the one of the perpetrators of the collapse of his power? (Leonov, 2015).

All Fidel's and Raul Castro's biographers try to understand why the quite wealthy children of a major landowner, who were on a wide road to politics or business, became revolutionaries, changed Cuba radically and even destroyed their own estate. And no one finds a reasoned answer (Lago, 2012).

After the graduation from the high school, Raúl followed the footsteps of his charismatic brother and went to Havana in 1950. There he entered the preparatory courses at the University in the capital of Cuba, after which he became a student of the Faculty of Law of the University, with the specialization on "management" (Gugnin, Ostasz, Gugnina, Gierczak, 2012).

He took active part in the youth movement, participated in the organization and conduction of José Martí Followers' National Congress for Human Rights. His participation in the youth movement was so active that at the beginning of the following year Raúl got an invitation to go to Vienna and to attend the International Conference on Youth Rights as the head of the Cuban delegation.

At that time Vienna was still under the occupation of the allied forces and the conference delegates were forced to live in the Soviet sector, in a dilapidated hotel. According to Nikolai Leonov, the Russian biographer, who knew the Cuban revolutionary for more than half of a century, his father Don Angel became mad before the trip: "I won't give you a cent for a trip beyond the Iron Curtain!” But then he softened up and allowed to send Raúl 500 dollars (Leonov, 2015). 
Upon his return to the homeland, Raúl plunged into a serious political struggle: he became the member of the People's Socialist Party of Cuba (Communists). Raúl's biographers were interested in the reaction of his older brother to this decision. The answer to this question can be found in the book "100 Hours with Fidel" by Ignacio Pionet, the French writer, published in 2006: "Raúl was a person with certain left-wing beliefs, and in fact I was the one who told him about the Marxist-Leninist ideology. His entrance to the youth organization of the Communist Party met his understanding of Marx's teachings. To Pionet's surprised question: "Did he join the party by his own decision? - Fidel replied: "Yes, he always had his own views" (Pionet, 2016).

\section{CHARACTER-BUILDING IN THE FIGHT - FROM MONCADA TO ESCAMBRAI}

Raúl Castro was in the vanguard of 124 young men who, on 26 July 1953, stormed the Moncada barracks in Santiago de Cuba, Cuba's second most important military facility. It is necessary to note that until the last moment Raúl did not know what object was chosen by his older brother for the attack of the revolutionaries. Fidel told his plans to the participants of the operation only an hour before the scheduled time of the assault. Raúl headed the group that captured the Palace of Justice and, thus, distracted the Batista's armed forces from the actions of the squad led by his older brother. Alas, Maxim Makarychev, Fidel's Russian-speaking biographer regrets, "due to the chain of ridiculous accidents, young people were defeated by Batista's government troops" (Makarychev, https). Then inhuman tortures waited for them: the heroes of Moncada's capture were thrown from the rocks, their genitals were cut out, air was injected into their veins by syringes, and, finally, they were beheaded.

Two days earlier than Fidel Raúl was arrested on his way to their home estate in Biran. He told different name, trying to pretend to be a man who was coming back from the carnival in Santiago. He was taken to the commandant's office to check his identity. And only there, absolutely occasionally, by the evidence of a man, who recognized him, it turned out that the young man, playing with the police, was the younger brother of the main organizer of the daring attack. Raúl Castro was sentenced to 13 years in prison. After two years in prison with his brother and other comrades, who survived, he was released according to the amnesty law taken by the Cuban Congress (Jayatilleka, 2007).

On December 2, 1956, the legendary yacht "Granma" (Grandmother) moored on the south-eastern coast of the country. In his notes Che Guevara compared the landing itself with the shipwreck. Raúl Castro said later that in the dawn of the darkness it was difficult to see the contours of the coast and a terrible thought drilled his head: "What happens if we landed not on the shore, but on the one of the many islands covered with mangroves?" (Castro, Archivo). On December 2, 1978, one of the authors of this article, who worked at that time at the University of Holguin, managed to visit the landing place on the anniversary of the historic occasion. There was only one thought: "Horror!". Because of the traitor, who gave out the plans of the revolutionaries, the army of Batista destroyed the troop almost completely with the help of army aviation. 13 persons survived out of 82, including Raoul, Fidel and Che Guevara. After that, Raúl began his military career in the Rebel Army next to his brother and Ernesto Che Guevara, with whom he became very close. Numerous victorious fights brought him the rank of Commander in February 1958 (Anderson, 2010). 


\section{COMMANDER RAÚL IN ACTION}

On July 2-3, 1958, the negotiations were held between Commander Raúl Castro and the U.S. consul, who came from Santiago de Cuba to the "partisans republic" in the north of Oriente province. Raúl was accompanied by several front officers and Wilma Espin (his future wife, with whom he lived for almost 50 years), who was as an interpreter. Negotiations were held in the presence of several American prisoners and journalists from the United States and Brazil. The consul left soon with four Americans and one Canadian, but he came back to the partisans' location in only two days, shaking by the New York Times newspaper, which reported that Castro, the coordinator of the July $26^{\text {th }}$ movement, made an order to release all American prisoners. The American public, not knowing the final goal of the rebels, welcomed the noble deed of the Cuban leader (Martínez-Fernández, 2014).

Being the commander of the Second Front, Raúl Castro got the order to consolidate all disparate armed groups in the north of the province. Raul managed to create five new partisans' troops out of the new recruits. The partisans' active actions under his leadership led to the establishment of a revolutionary power on the territory of the Oriente province, which size is equal to the half of Belgium. Raúl bravely took the responsibility for all his actions within Fidel's strategy. The leadership of the Second Front became a real life university for him, where, according to his biographers, he was formed "not only as a military leader, but also as a mature politician and statesman" (Leonov, 2015).

In January 1959 as a result of the victories of the revolutionaries, the commander of the garrison of government troops numbering to five thousand people, asked Fidel to meet him. Colonel Rubido said he was ready to surrender the garrison, but he was not sure of the position of most of the officers. Raúl suggested immediately to go to the garrison with his brother, but Fidel had other solution. He sent Raúl there alone and his task was to convince the entire regiment that there was no sense to support the already collapsed regime (Skierka, 2008).

Raúl, who was jokingly called a "slammer" by his comrades-in-arms, could not refuse his older brother. Wilma Espin insisted on going with him, but Raúl did not agree and entered the fortress of Moncada almost alone, accompanied only by a bodyguard. In the bright sunlight he saw the entire regiment staying on the square. According to witnesses, after negotiations with officers Raúl ripped off the portrait of Batista, threw it on the floor and shouted: "Long live the revolution!". After a minute pause, the soldiers exhaled "Long live!" The officers asked Raúl to address the assembled soldiers. In a brief speech he described the revolution and promised the soldiers of the garrison a raise, not given by the previous government. At the end, Raúl invited the senior officers of the garrison to meet the commander of the garrison en Hefe in an agreed place (Leonov, 2015).

Raul Castro was in the Orient province until February 9, 1959, when Fidel called him to Havana and gave the position of the Deputy Commander of the Armed Forces. The revolutionary confrontation ended with Batista's escape and people's unconditional victory. The nationwide enthusiasm, multiplied by the clear strategy of the Castro brothers, was a decisive factor in this victory.

\section{THE SECOND PERSON IN THE CREATION OF A NEW SOCIETY}

Raúl became the second person in the state and later in the party he "was Fidel's permanent understudy at all political and state posts" (Dabagyan, 2016). Raúl Castro 
became the ministry of defense in October 1959 and was on this position till February 24, 2008, when he officially became the President of Cuba. On 22 December 1975, at the first congress of the Cuban Communist Party, Raúl Castro was elected to be a Second Secretary of the Central Committee.

Fidel, while presenting his brother's candidacy, talked about him for the first time after the revolution: "As for Comrade Raúl, I can say one thing: I am honoured that such an outstanding figure in the revolution is my brother. Raúl gained his authority in struggle, which he was among the first to join. Our family relations allowed only to involve him in the revolutionary process, to attract him to Moncada capture. And I remember that when a patrol broke into the courthouse in Santiago de Cuba and arrested Raúl's group ... he snatched the gun from the patrol's chief and managed to capture the patrol that had arrested his comrades. If he hadn't done so, they would have been killed in Moncada in a few hours" (Makarychev, ${ }^{2017)}$.

The Castro brothers kept the posts of the first and second secretaries of the Central Committee of the Communist Party of Cuba, the chairman and his first deputy of the State Council of the Republic, the prime minister and his first deputy, the supreme commanderin-chief and the minister of defense of the country for about half a century. Thus, Raisa Karakhanova, the Russian researcher told, "the leading Communist Party, administrative and administrative structures of the state apparatus, law enforcement agencies were subordinated to the Castro brothers for many years, which ensured the stability in the country's" (Karahanova, 2018).

This idea echoes another idea by Ksenia Konovalova that the political elite in Latin American countries, as a creative minority of government officials, "turns out to be personified" (Konovalova, 2018). In other words, it is "associated more with bright individual personalities than with any formalized groups, pre-established tools and methods of concentration and administration of power" (Konovalova, 2018).

But the execution of the second leader's functions did not always go smoothly. In his book Leonov cites excerpts from an interview of Raul with a Mexican journalist in 1993. He told about the dramatic trip to Moscow in December 1982, which Fidel sent his brother to. The purpose of the trip to the USSR was to bring to the attention of the Soviet leadership an opinion that due to the anti-Cuban aggression in the Reagan administration it is necessary to take urgent political and diplomatic steps in order to prevent and to stop the renewed threats of Americans, which were going to make a military strike to the island.

According to the Cuban side, such steps should had been made in the form of an official Soviet warning to the United States. The warning should show that the Soviet Union would not tolerate aggression against Cuba. Raúl Castro expressed such views to Yuri Andropov. The answer of the highest Soviet leader was categorical: "In case of American aggression against Cuba we cannot conduct military operations there, because you are 11,000 km away from us", - and he added - "we will not go there for them to beat us up" (Leonov, 2015).

Of course, the USSR promised to provide political and moral support and to continue to supply weapon in accordance with the current program. This was the biggest diplomatic defeat of Raul Castro. He hoped for a positive solution of the issue, as in the Kremlin he was considered to be a firmer communist than Fidel.

That's why, at a meeting of the Politburo after his return from Moscow Fidel said that this issue was very dangerous in case of a leak of information about it and it should be left to the competence of the first and second secretaries. The Politburo agreed with this opinion. 
The year 1991 became a time of the most acute economic crisis for Cuba, which was related to the collapse of socialism. Raúl Castro had not only felt the inevitability of the disaster in advance, but he had also taken steps to mitigate its effects. Back in April 1990, almost a year before the collapse of the Soviet Union, he convened a meeting of the highest leaders of the party, government structures and the highest command of the armed forces of the country in the province of Pinar del Rio. There, for the first time, the term "special period" was used to describe the situation. The meeting was devoted to the correlation between the economy and defense capabilities. A special exhibition was held in front of the participants, where the products and technologies, necessary to overcome the difficulties of a special period, were presented. The emphasis was made on the home production of spare parts for the imported equipment, on the production of feeds for animal husbandry based on domestic raw materials, the use of local materials for the creation of pharmaceutical products.

At the end of the meeting Raúl said: "In everything that is connected with the thrift, rational use and austerity, you should consider that we live in a special period" (Karahanova, 2018). By Raoul's order, the exhibition was shown later to the leaders of all levels of the party and state apparatus. Special preparations were held in military units, party and state structures in order to prepare the armed forces and the entire society for the upcoming difficulties. Since the beginning of 1990, by Raúl's order around 1,800 detailed recommendations have been developed and implemented in the Cuban Revolutionary Armed Forces in order to save as much as possible resources without compromising the country's defense capabilities. The army assumed the responsibility for almost $85 \%$ of its self-sufficiency.

Generally speaking those, who passed the Cuban army school, remember that Raúl Castro's style of work was characterized by a high level of exactingness, rigidity of criticism of shortcomings, and at the same time by his skill to soften the "spread under the curtain". Those who were criticized didn't leave with the sense of hopelessness and oppression in their hearts (Baez, 2014).

\section{THE PRESIDENT}

On July 31, 2006, Raúl Castro took temporary leadership of the country due to Fidel's health problems. "The power was taken by Raul Castro, who was in the shadow of his brother for over a half of a century. Without Fidel's charisma and being in the shadow for many years before, he managed to rule Cuba with dignity, without crises and failures, as broadcasters from Florida predicted. Moreover, he started the big changes on the island" (Makarychev, 2017). When on 24 February 2008 he became the President, he took a courageous decision and started the historic phase of adjustments in the domestic and foreign policy. Speaking on his election in the Parliament, Raúl Castro quilted: "You elected me to be the Chairman of the State Council not to restore capitalism in Cuba; not to betray the revolution. I was elected to defend, strengthen and improve socialism" (Karahanova, 2018).

Since the late 1980s Raúl had a reputation of a liberal. The package of laws was adopted by his initiative. That package legalized partially the individual entrepreneurship, opened the Cuban economy to foreign investments and thereby absorbed the impact of the worst crisis of the 1990s (Karahanova, 2018). From the very beginning, the Raúl Castro government announced a program of spending cuts. The list of basic necessities that had 
previously been available by cards for almost nothing, was reduced. In this regard Raúl expressed himself directly: "Cuba must stop to be the only place on earth where you can live without working" (Makarychev, 2017). This was explained by an attempt to stop the deepening crisis and to save the public sector of the economy. In one of its issues, the "Granma" newspaper quoted Fidel Castro, who said in 1986: "No state can give its citizens what it does not have" (Masiubańska, Masiubański, Montenegro, 2016).

Even though Raúl's reforms began in 2008, the main guidance for its implementation was based on the decisions of the 6th Communist Party Congress in spring 2011, the socalled "Directions of the Party's Economic and Social Policy and Revolution". They set the course for employment restructuring, labor productivity increase and search for alternative sources of financing. A number of improvements in the private sector, the conditions of sale and purchase of movable property and real estate, the use of the Internet and mobile communications have changed the picture of ordinary Cubans' lives markedly. Private business was legalized in 178 areas of the professional activity, travels abroad were allowed, and the process of housing privatization began. At the same time, Raúl repeatedly stated that reforms should never "import neoliberal formulas and shock therapy into Cuba in lives of the poorest people" (Kozdoyev, 2019).

Raúl Castro made significant changes to the Cuban model of socialism. He set the new path for the country, which was a big step forward. However, not all his plans were implemented, and some of them didn't bring the expected results. In his report to the 7th Congress of the Communist Party in April 2016, the head of the state said that only $21 \%$ of the 313 approved directions had been implemented. $77 \%$ were in the process of the implementation, and $2 \%$ have not been started yet. The implementation of the Five-Year Plan (2011-16) showed the main obstacles in the planned course. This is "a ballast of outdated thinking of the part of establishment, which does not allow getting out of illusory hopes for external assistance. On the other hand, there are also disguised attempts to restore capitalism" (Roke, 2016). The words of the Cuban leader clearly show that the choice was made in favor of a mixed economic system. In his report, Raúl noted the necessity for "the recognition of the market together with the functioning of the socialist economy" (Roke, 2016).

Without large reserves of necessary raw materials, a strong production infrastructure and modern technology, Cuba is largely dependent on external relations. Therefore, Raúl's internal reforms were accompanied by changes in the nature of the foreign policy. Havana began to cooperate actively with the countries of Latin America, Europe and the AsiaPacific region. The most important catalyst for these processes was the normalization of the American-Cuban relations.

On December 17, 2014, after long secret negotiations, Raúl Castro announced the agreement, which was reached between the Cuban and American authorities in order to restore diplomatic relations and to start the process of normalization of relations between Havana and Washington. In the next two years both governments took concrete steps to ease some of the U.S. sanctions against Cuba, which were the part of the economic, commercial and financial embargo imposed by Washington in 1961.

In March 2016, US President Barack Obama made a historic visit to Cuba. Meeting the honored guest, Raúl Castro was full of dignity and still unbended. He stopped Obama from patting himself on the shoulder during the farewell ceremony at the airport. 


\section{SUMMARY}

Summing up the analysis of Raúl reforms, it should be noted that the infringement of political and civil rights was practically not abolished. The existence of a single-party system and the constitutional refusal to separate the branches of power allows to talk about serious lameness of Castro's political system and the absence of the most important instrument of democratic checks and balances in Cuba, which would ensure the implementation of political rights. In particular, during the reign of Raúl Castro there was a number of restrictions in the sphere of civil rights: a constitutional ban on the creation of private media; a complicated procedure for the country's leaving, expressed in the necessity to obtain the permission to leave the country; difficulties in establishing new religious associations and the supervision of them by the state authorities (Elbaeva, 2010).

Raul Castro resigned as president in 2018. His successor was 57-year-old Miguel DiazCanel, whose promotion was made under the close supervision of Raúl (similar to his promotion by Fidel). Raúl Castro introduced the future president to the Politburo in 2003 and appointed him to be the Minister of Higher Education in 2009. Even when Diaz-Canel was elected the head of state, Raúl Castro, who kept the post of the first secretary of the Communist Party, said about the successor in a very symptomatic way: "He is not a pop up, he is not an improvisation, he just stayed behind the scenes during the last time" (Konovalova, 2018).

Raul didn't leave the politics. Speaking at a meeting of the National Assembly of People's Power this spring, he said that U.S. actions are becoming more and more aggressive and are continuously undermining the bilateral relations. According to him, "Havana notified Washington through open diplomatic channels that Cuba is not afraid of threats and sanctions of Trump, it will persistently follow the socialist path, will protect the future of the state from the interference of other countries and will protect the cause of peace" (Comments «IA SinChua», 2019).

Nowadays the biographers of Cuban leaders note that "Raúl's main enemy is not Americans (Makarychev, 2016), but the age and time, which are inexorably running out, and, despite the other enemies, these ones he cannot overcome or, at least, curb.

\section{REFERENCES}

Anderson, J.L. (2010). Che Guevara: A revolutionary life. New York: Grove Press.

Baez, L. (2014). Hay que salvar la esperanza. "Granma”, 17 de abril.

Castro, R. Diario de campana. Archivo del Comite Central del Partido Comunista de Cuba.

Comments «IA SinChua». (2019). Access on the internet: https://news.rambler.ru/usa/ 42018235-kuba-ne-boitsya-ugroz-ssha-raul-kastro/2019/04/11.

Dabagyan, E. (2016). Raul Castro's roles. «Latin America», № 6.

Eckstein, S.E. (2003). Back from the future: Cuba under Castro. New York: Routledge.

Elbaeva, M.V. (2010). Human rights on Cuba: the influence of domestic and external factors on its development. Dissertation thesis on $\mathrm{PhD}$ degree in historical sciences, Moscow.

Farber, S. (2006). The Origins of the Cuban Revolution: Reconsidered. The University of North Carolina Press.

Gugnin, A., Ostasz, G., Lisnevskaya, Y. (2019). Fidel Castro as a leader, revolution manager, and marketer. "Advances in Social Science, Education and Humanities Research", Vol. 318.

Gugnin, A., Ostasz, G., Gugnina, T., Gierczak, A. (2012). Politics and Marketing: An Attempt at Structural and Functional Analysis. Rzeszow: Amelia. 
Huberman, L., Sweezy, P.M. (1961). Cuba: Anatomy of a revolution. New York: Monthly Review Press.

Jayatilleka, D. (2007). Fidel's Ethics of Violence: The Moral Dimension of the Political Thought of Fidel Castro. London: Pluto Press.

Kapcia, A. (2014). Leadership in the Cuban Revolution: The unseen story. London: Zed Books Ltd.

Karahanova, R. (2018). Raul Castro. The magazine of the historical faculty of MSU. «Historical researches», №9.

Kozdoyev, M.A-M. (2019). Raul Castro and his reforms. The magazine of the historical faculty of MSU. «Historical researches», №9.

Konovalova, K. (2018). Castro and others: few words on the political elite of modern Cuba. Science and culture, SpbSU, №5.

Lago, G.N. (2012). Cuba en la era de Raul Castro. Madrid: Colibri.

Leonov, N. (2015). Raul Castro. Moscow: Publ. Molodaya Gvardiya.

Lievesley, G. (2004). The Cuban Revolution: Past, Present and Future Perspectives. New York: Palgrave MacMillan.

Makarychev, M. (2016). Cuba's President Raul Castro is 85. Access on the internet: https:// rg.ru/2016/06/03

- (2017). Fidel Castro. Moscow: Publ. Molodaya Gvardiya.

Martínez-Fernández, L. (2014). Revolutionary Cuba: A history. Florida: University Press of Florida.

Masiubańska, J., Masiubański, J., Montenegro, O. (2016). Nowy Castro, stara Kuba. Konin: Psychoskok.

Pionet, I. (2016). 100 hours with Fidel. Havana: Cuba's state council publishing.

Roke, G.K. (2016). VII Congress of Cuban Communist Party Report. The institute of the World History of RAS. "Latin American historical magazine”. Part 17.

Skierka, V. (2008). Fidel Castro. Wrocław: Wyd. Dolnośląskie.

Why Raul doesn't look similar to Fidel. „Nevskoe vremya”, SPb, 25.05.2019.

DOI: $10.7862 /$ rz.2020.hss.17

The text was submitted to the editorial office: March 2020.

The text was accepted for publication: June 2020. 
